\title{
AKHLAK PELAJAR DITINJAU DARI KITAB ADAB AL-ALIM WA AL- MUTA'ALLIM
}

\author{
Nailul Fitria Afifah 1)* \\ Sania Ro'ifah 2) \\ ${ }^{1}$ Program Sarjana Pendidikan Islam, \\ Institut Agama Islam Negeri Kudus (IAIN KUDUS) \\ 2 Program Sarjana Pendidikan Islam, \\ Institut Agama Islam Negeri Kudus (IAIN KUDUS) \\ *E-mail: Nailulfitria25@gmail.com
}

\begin{abstract}
Understanding of the concept of learning in Islamic education and also the concept of student ethics according to Kyai Haji Hasyim Asy'ari in the book adab Ta'lim Muta'alim. The purpose of this study is so that student tools in learning can facilitate the achievement of appropriate character education. The results of the study state that the principle that students must have is a pure heart straightens out the intention to seek knowledge qanaah can divide the time to reduce eating and drinking reduce sleep and avoid association with the opposite sex. The method in this study is that student library research in the view of Kyai Haji Muhammad Hasyim Asy'ari is a person who must have full continuity and concentration in participating in learning activities that have high morality and motivation so that students are not trapped in pragmatism pragmatism while seeking knowledge.
\end{abstract}

Keywords : Morals, Ta'lim Muta'alim

\begin{abstract}
Abstrak
Pemahaman tentang konsep pelajar dalam pendidikan Islam dan juga konsep etika pelajar menurut K.H. M. Hasyim Asy'ari dalam kitab Adab Al-Alim Wa Al-Muta'allim. Tujuan penelitian ini adalah agar akhlak pelajar dalam menuntut ilmu dapat mempermudah pencapaian yang sesuai pendidikan karakter. Hasil penelitian menyatakan bahwasannya akhlak yang harus di miliki pelajar adalah hati yang suci, meluruskan niat mencari ilmu, qona'ah, bisa membagi waktu, mengurangi makan dan minum, mengurangi tidur, wira'i, dan menghindari pergaulan dengan lawan jenis. Metode dalam penelitan ini adalah penelitian pustaka. Pelajar menurut pandangan KH. M. Hasyim Asy'ari adalah seseorang yang harus memiliki kontinuitas dan konsentrasi penuh dalam mengikuti kegiatan belajar yang dilaksanakan, memiliki moralitas dan motivasi yang tinggi, sehingga pelajar tidak terjebak pragmatisme-pragmatisme ketika sedang mencari ilmu.
\end{abstract}

Kata Kunci : Akhlak, Ta'lim Muta'alim

\section{PENDAHULUAN}

Semua perbuatan yang bersifat keagamaan, baik yang bersifat bathiniyah maupun lahiriyah, baik ucapan maupun perbuatan, hal itu tidak akan dianggap sebagai amal, kecuali apabila perbuatan tersebut di barengi dengan budi pekerti yang baik, sifat-sifat yang terpuji dan akhlak yang mulia. Karena menghiasi amal perbuatan 
dengan budi pekerti yang baik diwaktu sekarang itu merupakan tanda diterimanya amal suatu saat nanti, di samping budi pekerti yang baik sebagaimana di butuhkan oleh seorang pelajar ketika ia belajar, seorang guru juga membutuhkannya ketika proses belajar mengajar.

Ketika derajat akhlak sudah mencapai pada tingkatan ini, sementara ketentuan kriteria akhlak secara detail belum jelas, maka apa yang belum aku lihat, yakni kebutuhan para pelajar akan budi pekerti dan susahnya mengulang-ulang untuk mengingatkan kesalahan akhlak mereka, telah mendorong aku untuk mengumpulkan risalah ini sebagai pengingat pribadiku sendiri khususnya dan umumnya orang-orang yang memiliki wawasan dangkal. Kedudukan pelajar dalam proses pendidikan sangat penting. Pelajar sebgai manusia yang belum dewasa merasa tergantung terhadap pendidikannya, ia merasa memiliki kekurangan - kekurangan tertentu, ia menyadari bahwa kemampuannya masih sangat terbatas dibandingkan dengan kemampuan pendidikannya.

Bahwasannya dari penjelasan di atas, penulis merasa tertarik untuk menjadikan kitab Adab Al-alim Wa al-Muta'allim karya KH. M. Hasyim Asy'ari sebagai objek kajian dalam penulisan ini, karena kitab ini berbicara langsung tentang akhlak dalam pendidikan Islam. Penulis memilih KH. M. Hasyim Asy'ari sebagai tokoh utama dalam penelitian ini karena beliau adalah seorang pendidik, ulama' besar dan masyhur yang banyak melahirkan ulama'-ulama' besar di tanah Jawa yang tidak diragukan lagi kapasitas keilmuannya, pemikiran-pemikirannya banyak kita jumpai dalam berbagai bnodang keilmuan.

Penulis merasa tertarik untuk mengkaji lebih dalam mengenai akhlak yang harus diterapkan seorang pelajar dalam menuntut ilmu dengan memfokuskan pada kitab Adab Al-alim Wa al-Muta'allim karya KH. M. Hasyim Asy'ari dan seperti apa relevansinya dengan tujuan pendidikan nasional dengan harapan semoga hasil penelitian ini dapat memberikan manfaat bagi para pemerhati pendidikan dan solusi atas problematika pendidikan yang terjadi saat ini.

\section{METODE}

Jenis dalam penelitian ini adalah penelitian pustaka. Waktu mengenai hasil penelitian adalah ba'dha subuh, tepatnya ketika ngaji subuh bertempat di Pondok Pesantren Entrepreneur Al-Mawaddah Honggosoco Kudus. Sasaran penelitian ini 
adalah kajian kitab Adab Al-alim Wa al-Muta'allim dan santri-santri, analisis melalui terjemah sekaligus perilaku para santri dalam mengaplikasikan. Instrumen penelitian berupa dokumen dan wawancara serta penelitian yang mengenai akhlak baik dan tercela yang diterapkan oleh santri-santri setiap harinya. Bagaimana cara mengkaji kajian terhadap santri-santri dalam kajian kitab Adab Al-alim Wa al-Muta'alim kedalam ranah yang Entrepreneur.

Penelitian ini menggunakan pendekatan kualitatif. Data berupa dokumen, terjemahan kitab dan kitab Adab Al-alim Wa al-Muta'allim yang asli. Instrumen penelitian berupa panduwan wawancara, buku catatan, dan alat rekam. Teknik pengumpulan data berupa data angket (kuesioner) dan pengumpulan data stady pustaka.

\section{PEMBAHASAN}

Akhlak berasal dari kata bahasa arab akhlaqo jamak taksir dari kholaqo dan sudah mengalami penyerapan kedalam bahasa Indonesia yang dapat diartikan sebagai perangai atau kesopanan. akhlak adalah suatu istilah agama yang digunakan untuk menilai setiap aktivitas perbuatan manusia apakah berada dalam katagori baik atau buruk. Pengertian akhlak adalah suatu perilaku yang menghubungkan antara Allah dan makhluknya.

Akhlak menyangkut kondisi Internal, suasana batin seseorang sebagai individu. Para ahli atau cendekiawan telah banyak memberikan pengertian akhlak. bagaimana pengertian akhlak menurut mereka? berikut ini beberapa pengertian akhlak menurut para ahli. Menurut Abu Hamid Algazali : Akhlak adalah satu sifat yang terpatri dalam jiwa yang dirinya terlahir perbuatan - perbuatan dengan mudah tanpa memikirkan dirinya dan merenung terlebih dahulu.

Menurut Muhammad bin Ali Asy Syarif Al-Jurjani : Akhlak adalah suatu sifat baik dan buruk yang tertanam kuat dalam diri yang darinya terlahir perbuatan - perbuatan dengan mudah dan ringan tanpa perlu berfikir dan merenung. Menurut Akhmad bin Musthafa : Akhlak adalah ilmu yang darinya dapat diketahui jenis - jenis keutamaan dan keutamaan itu adalah terwujudnya keseimbangan antara tiga kekuatan, kekuatan berfikir, kekuatan marah dan kekuatan syahwat. Menurut Ibnu Maskawih : Akhlah adalah 'hal li an-nafsi daa'iyatun lahaa ila af'aaliha min goiri fikrin walaa ruwiyatin' 
yakni sifat yang tertanam dalam jiwa yang mendorongnya untuk melakukan perbuatan tanpa memerlukan pemikiran dan pertimbangan.

Jadi, dari beberapa pendapat tentang akhlak diatas pada hakikatnya tidak ada perbedaan yang mendasar mengenai pengertian tersebut. Akhlak merujuk pada kebiasaan kehendak. Bahwasannya kalau kehendak itu dibiasakan itulah yang dinamakan akhlak. Misalnya, kalau kehendak untuk membiasakan memberi maka ini dinamakan akhlak dermawan. Budi adalah sifat jiwa yang tidak kelihatan, sedangkan akhlak adalah kelihatan melalui kelakuan atau muamalah. Kelakuan adalah bukti dan gambaran adanya akhlak.

Setiap pelajar harus menata niatnya ketika akan belajar karena niat adalah pokok dari segala amal ibadah, Rasulullah bersabda "Banyak perbuatan atau amal yang tampak dalam bentuk amalan keduniaan, tapi karena di dasari niat yang baik (ikhlas) maka menjadi atau tergolong amal akhirat. Sebaliknya banyak amalan yang sepertinya tergolong amal ibadah akhirat, kemudian menjadi amal dunia, karena didasari niat yang buruk (tidak ikhlas)."

Setiap orang islam juga wajib mengetahui atau mempelajari akhlak yang terpuji dan yang tercela, seperti watak murah hati, kikir, penakut, pemberani, merendah diri, congkak, menjaga diri dari keburukan, israf (berlebihan), bakhil terlalu hemat dan sebagainya. Sifat sombong, kikir, penakut, israf hukumnya haram dan tidak mungkin bisa terhindar dari sifat-sifat itu tanpa mengetahui kriteria sifat-sifat tersebut serta mengetahui cara menghilangkannya. oleh karena itu orang wajib mengetahuinya. AsySyahid Nasyiruddin telah menyusun kitab yang membahas tentang akhlak. Kitab tersebut sangat bermutu, dan perilaku dibaca, karena setiap orang wajib memelihara akhlaknya. Akhlak pelajar terhadap dirinya sendiri ada sepuluh macam, yaitu:

1. Mensucikan hatinya dari setiap yang mempunyai unsur menipu, kotor, dendam, hasud, keyakinan yang tidak baik, dan budi pekerti yang tidak baik, hal itu dilakukan supaya ia pantas untuk menerima ilmu, menghafalkannya, meninjau kedalaman maknanya dan memahami makna yang tersirat.

2. Memperbaiki niat dalam mencari ilmu, dengan tujuan untuk mencari ridha Allah SWT, serta mampu mengamalkannya, menghidupkan syari'at, untuk menerangi hati, menghiasi batin dan mendekatkan diri kepada Allah SWT. Tidak bertujuan untuk memperoleh tujuan-tujuan duniawi, misalnya menjadi pimpinan, jabatan, harta benda, mengalahkan teman saingan, agar dihormati masyarakat dan 
sebagainya. Setiap pelajar harus menata niatnya ketika akan belajar karena niat adalah pokok dari segala amal ibadah, Rasulullah bersabda "Banyak perbuatan atau amal yang tampak dalam bentuk amalan keduniaan, tapi karena di dasari niat yang baik (ikhlas) maka menjadi atau tergolong amal akhirat. Sebaliknya banyak amalan yang sepertinya tergolong amal ibadah akhirat, kemudian menjadi amal dunia, karena di dasari niat yang buruk (tidak ikhlas)."

3. Pelajar harus berusaha sesegera mungkin memperoleh ilmu di waktu masih belia dan memanfaatkan sisa umurnya, jangan sampai tertipu dengan menunda-nunda belajar dan terlalu banyak berangan-angan. Karena setiap jam akan melewati umurnya yang tidak mungkin diganti atau ditukar. Seorang pelajar harus memutuskan urusan-urusan yang merepotkan yang mampu ia lakukan juga perkara-perkara yang bisa menghalangi kesempurnaan mencari ilmu serta mengerahkan segenap kemampuan dan bersungguh-sungguh dalam menggapai keberhasilan. Maka sesungguhnya hal itu akan menjadi pemutus jalan proses belajar.

4. Pelajar harus menerima apa adanya atau qanaah terhadap segala sesuatu yang mudah ia dapat, baik itu berupa makanan atau pakaian dan sabar atas kehidupan yang berada dibawah garis kemiskinan yang ia alami ketika dalam tahap proses mencari ilmu, serta mengumpulkan morat-maritnya hati akibat terlalu banyaknya angan-angan dan keinginan sehingga sumber-sumber hikmah akan mengalir ke dalam hatinya.

Imam Syafi'i telah berkata, "Orang yang mencari ilmu tidak akan bisa merasa bahagia apabila ketika mencari ilmu disertai dengan hati yang luhur dan kehidupan yang serba cukup, akan tetapi orang-orang yang mencari ilmu dengan perasaan hina rendah hati kehidupan yang serba sulit dan menjadi pelayan para ulama dialah orang yang bisa merasakan kebahagiaan".

5. Harus bisa membagi waktu dan menggunakan setiap kesempatan hidupnya dengan, karena waktu tidak ternilai harganya. Waktu yang paling ideal dan baik digunakan oleh para pelajar:

a. Waktu sahur digunakan untuk menghafal.

b. Waktu pagi digunakan untuk membahas pelajaran.

c. Waktu tengah hari digunakan untuk menulis.

d. Waktu malam digunakan untuk meninjau ulang dan mengingat pelajaran. 
Sedangkan tampat yang paling baik digunakan untuk menghafalkan adalah di dalam kamar dan tempat yang dapat meningkatkan konsentrasi agar jauh dari sifat lupa. Tidak baik menghafal pelajaran di dekat tumbuh-tumbuhan, tanamantanaman yang hijau, di tepi sungai dan di tempat-tempat yang ramai.

6. Mengurangi makan dan minum, karena apabila perut dalam keadaan kenyang maka akan mengurangi semangat ibadah dan badan menjadi berat. Salah satu manfaat mengurangi makan adalah badan menjadi sehat dan mencegah timbulnya penyakit. Karena penyebab timbulnya penyakit adalah terlalu banyak makan dan minum, sebagaimana yang dikatakan dalam sebuah syair: "Terlalu banyak makan dan minum menimbulkan penyakit"

Sedangkan sehatnya hati itu terhindar dari perbuatan lacur, melampaui batas dan sombong. Tidak ada para pemimpin umat /ulama yang punya kebiasaan banyak makan. Banyak makan hanya cocok untuk binatang ternak karena binatang dipersiapkan untuk bekerja keras.

7. Harus Bersifat Wira'i (menjaga diri dari perbuatan yang bisa merusak harga diri), serta berhati-hati dalam setiap keadaan, memperhatikan kehalalan makanannya, baik itu berupa makanan, minuman, pakaian, tempat tinggal dan setiap sesuatu yang ia butuhkan, agar hatinya terang dan pantas untuk menerima ilmu, cahaya ilmu dan mengambil kemanfaatan ilmu. Sebaiknya pencari ilmu juga menggunakan kemudahan-kemudahan (rukhsah) pada tempatnya ketika dibutuhkan a nada sebab-sebabnya, karena Allah menyukai kemudahankemudahan (rukhsah) yang dilaksanakan sebagaimana Dia menyukai ketetapanketetapan Nya (azimah) dilaksanakan.

8. Harus mengurangi makanan yang bisa menyebabkan berkurangnya kecerdasan (dedel: Jawa), lemahnya panca indra, seperti: buah apel yang masam, buncis, minum cuka'. Begitu juga makanan berlemak yang dapat mengurangi kecerdasan dan menambah berat badan, seperti: terlalu banyak minum susu, makan ikan dan lain sebagainya. Sebaiknya juga ia menjauhkan diri dari hal-hal yang menyebabkan lupa secara khusus, seperti: memakan makanan yang telah dimakan tikus, membaca tulisan di batu nisan (pathok kuburan), masuk di antara 2 ekor unta yang ditarik dan menjatuhkan kutu dalam keadaan hidup.

9. Harus berusaha untuk mengurangi tidur selama tidak menimbulkan bahaya pada tubuh dan akal pikirannya. Jam tidur tidak boleh melebihi dari delapan jam dalam 
sehari semalam. Dan itu sepertiga dari waktu satu hari (dua puluh empat jam). Jika keadaannya memungkinkan untuk beristirahat kurang dari sepertiganya waktu dalam sehari semalam maka ia dipersilahkan untuk melakukannya. Apabila ia merasa terlalu lelah, maka tidak ada masalah untuk memberikan kesempatan beristirahat terhadap dirinya, hatinya dan penglihatannya dengan cara mencari hiburan, bersantai ke tempat-tempat hiburan sekiranya pulih kembali dan tidak menyia-nyiakan waktu.

10. Harus meninggalkan pergaulan, terutama dengan lawan jenis. Khususnya jika terlalu banyak bermain dan sedikit menggunakan akal fikiran, karena watak dari manusia adalah banyak mencuri kesempatan. Bahaya dari pergaulan adalah menyia-nyiakan umur tanpa manfaat dan berakibat hilangnya agama jika bergaul dengan orang yang tidak beragama. Jika ia membutuhkan teman, maka hendaklah orang yang shaleh, kuat agamanya, takut kepada Allah, wira'i, bersih hatinya, banyak berbuat kebaikan, sedikit berbuat kejelekan, memilki harga diri yang baik, dan tidak keras kepala. Jika ia lupa, maka temannya harus mengingatkan, dan jika ia ingat, maka temannya telah menolongnya.

\section{SIMPULAN DAN SARAN}

\section{A. Simpulan}

Pelajar menurut pandangan KH. M. Hasyim Asy'ari adalah seseorang yang harus memiliki kontinuitas dan konsentrasi penuh dalam mengikuti kegiatan belajar yang dilaksanakan, memiliki moralitas dan motivasi yang tinggi, sehingga pelajar tidak terjebak kepada paradigma pragmatisme-pragmatisme ketika sedang mencari ilmu. Etika pelajar menurut pandangan KH. M. Hasyim Asy'ari dalam kitab Adab Al-alim Wa al-Muta'allim, menyajikan sebuah konsep bahwa dalam menuntut ilmu pelajar dianjurkan untuk secara tekun dan fokus. Pelajar harus memberikan perhatian serius untuk mencapai keberhasilan proses belajar. Pada sisi lain, beliau juga menekankan pentingnya menyucikan jiwa dalam belajar.

\section{B. Saran}

Akhlak adalah sebuah hal yang tidak dapat dikesampingkan di era modern seperti saat ini. Oleh karena itu, pemahaman tentang akhalak di dalam kitab Adab 
58 | Nailul Fitria Afifah \& Sania Ro'ifah

Al-alim Wa al-Muta'allim menjadi penting untuk dipelajari dan dipahamai oleh setiap siswa.

\section{DAFTAR PUSTAKA}

Khasanah Uswatun, Etika Pelajar dalam kitab Adab Al-Alim Wa Al- Muta'allim Karya K.H. M. Hasyim Asy'ari dan Relevansinya dengan Tujuan Pendidikan Nasioanal, Yogyakarta UIN Sunan Kalijaga, 2015

Asy'ari Hasyim, Adab Al-Alim Wa Al- Muta'allim

Syeikh Az-Zarnuji, Terjemah Ta'lim Muta'alim, Surabaya : Mutiara Ilmu, 2009.

http://pengertianahli.id.com.14.ockt.2013.waktu13:16 